\title{
Physico-chemical and structural characterization of mucilage isolated from seeds of Diospyros melonoxylon Roxb.
}

\author{
Sudarshan Singh ${ }^{1, *}$, Sunil B. Bothara ${ }^{2}$ \\ ${ }^{I}$ Shree H. N. Shukla Institute of Pharmaceutical Education and Research, Rajkot, Gujarat, India, ${ }^{2}$ Rofel Shri GM Bilakhia \\ College of Pharmacy, Vapi, Gujarat, India
}

\begin{abstract}
Mucilage was isolated from the seeds of Diospyros melonoxylon Roxb., a plant growing naturally in the forests of India. Various physico-chemical methods like particle analysis, scanning electron microscopy, differential scanning calorimetry, differential thermal analysis, thermogravimetry analysis, molecular weight by gel permeation chromatography, rheometry, elemental analysis, $\mathrm{x}$-ray diffraction spectrometry, zeta potential, fourier transform infrared spectroscopy, $1 \mathrm{D}\left({ }^{1} \mathrm{H}\right.$ and $\left.{ }^{13} \mathrm{C}\right)(\mathrm{NMR})$ have been employed to characterize this gum in the present study. Particle analyses suggest that mucilage had particle size in nanometer. SEM analysis suggested that the mucilage had irregular particle size. The glass transition temperature of the gum observed was $78^{\circ} \mathrm{C}$ and $74{ }^{\circ} \mathrm{C}$ by DSC and DTA respectively. The Thermogravimetry analysis suggested that mucilage had good thermal stability with two stage decomposition. The molecular weight of mucilage was determined to be 8760 , by gel permeation chromatography, while the viscosity of mucilage was observed to be $219.1 \mathrm{cP}$. The XRD pattern of the mucilage indicated a complete amorphous nature. Elemental analysis of the gum revealed specific contents of carbon, hydrogen, nitrogen and sulfur. The major functional groups identified from FT-IR spectrum include $3441 \mathrm{~cm}^{-1}(-\mathrm{OH}), 1632 \mathrm{~cm}^{-1}(-\mathrm{COO}-), 1414 \mathrm{~cm}^{-1}(-\mathrm{COO}-)$ and $1219 \mathrm{~cm}^{-1}\left(-\mathrm{CH}_{3} \mathrm{CO}\right)$. Analysis of mucilage by paper chromatography and 1D NMR indicated the presence of sugars.
\end{abstract}

Uniterms: Diospyros melonoxylon Roxb./phytochemistry Diospyros melonoxylon Roxb./physicochemical characterization. Zeta potential. Thermogravimetry analysis. 1D NMR spectroscopy.

\begin{abstract}
Mucilagem foi isolada de sementes de Diospyros melanoxylon Roxb, uma planta que cresce naturalmente nas florestas da Índia. Vários métodos físico-químicos, como análise de partículas, microscopia electrônica, calorimetria diferencial de varredura, análise térmica diferencial, análise termogravimétrica, massa molecular por cromatografia de permeação em gel, viscosidade, análise elementar, espectrometria de difração de raios-x, potencial zeta, espectroscopia no infravermelho com transformada de Fourier, 1D $\left({ }^{1} \mathrm{H} \mathrm{e}{ }^{13} \mathrm{C}\right)(\mathrm{NMR})$ foram utilizados no presente estudo para caracterizar essa goma. A análise de partículas sugere que a mucilagem tem tamanho de partícula em $\mathrm{nm}$. A análise SEM sugere que a mucilagem tem tamanho de partícula irregular. Observou-se temperatura de transição vítrea da goma de $78{ }^{\circ} \mathrm{C}$ e $74{ }^{\circ} \mathrm{C}$ por DSC e DTA, respectivamente. A análise termogravimétrica sugeriu que a mucilagem possuía boa estabilidade térmica, com duas fases de decomposição. A massa molecular da mucilagem foi 8760, por meio de cromatografia de permeação em gel, enquanto que a viscosidade foi $219,1 \mathrm{cP}$. O padrão de DRX da mucilagem indicou natureza completamente amorfa. Os principais grupos funcionais identificados a partir do espectro de FT-IR foram: $3441 \mathrm{~cm}^{-1}$ (-OH), $1632 \mathrm{~cm}^{-1}$ (-COO-), $1414 \mathrm{~cm}^{-1}$ (-COO-) e $1.219 \mathrm{~cm}^{-1}$ $\left(\mathrm{CH}_{3} \mathrm{CO}-\right)$. As análises de mucilagem por cromatografia em papel e ${ }^{1} \mathrm{D} \mathrm{RMN}$ indicaram a presença de açúcares.
\end{abstract}

Uniterms: Diospyros melonoxylon Roxb./fitoquímica. Diospyros melonoxylon Roxb./caracterização físico-química. Potencial zeta. Análise termogravimétrica. Espectroscopia de RMN 1D.

\footnotetext{
*Correspondence: Sudarshan Singh. Department of Pharmaceutics. C/o. B. M. Kyada International School, Behind Marketing Yard, Near Lalpari Lake, Amargadh (Bhichari), 360001 - Rajkot - Gujarat, India. E-mail: sudarshansingh83@hotmail.com
} 


\section{INTRODUCTION}

In recent years, plant derived polymers have evoked tremendous interest due to their diverse pharmaceutical applications such as diluents, binders, disintegrants in tablets, thickeners in oral liquids, protective colloids in suspensions, gelling agents in gels and bases in suppository (Zatz, Kushla, 1989); they are also used in cosmetics, textiles, paints and paper-making (Jani et al., 2009).

The plant based polymers have been studied various research group for their application in different pharmaceutical dosage forms like matrix controlled system, film coating agents, buccal films, microspheres, nanoparticles, viscous liquid formulations like ophthalmic solutions, suspensions, implants and their efficacy have been reported (Pandey, Khuller, 2004; Chamarthy, Pinal, 2008; Alonso-Sande et al., 2009). These have also been utilized as viscosity enhancers, stabilizers, disintegrants, solubilisers, emulsifiers, suspending agents, gelling agents and bioadhesives, binders in the above mentioned dosage forms (Guo,et al., 1998).

By the term "mucilage in plants" is meant those substances which are soluble or at least swell very perceptibly in water and which, upon the addition of alcohol, are precipitated in a more or less amorphous or granular mass. Mucilage originates in the plant either as a part of the contents of the cell or as a part of the wall thereof.

Many natural polymeric materials have been successfully used in sustained-release tablets. These materials include: guar gum, isapghula husk, galactomannon from Mimosa scabrella, Gleditsia triacanthos Linn (honey locust gum), Sesbania gum, mucilage from the pods of Hibiscus esculenta, tamarind seed gum, gum copal and gum dammar, agar, konjac, chitosan etc. (Efentakis, Kouttis, 2001). Industrial gums and mucilage, which, for the most part, are water-soluble polysaccharides, have enormously large and broad applications in both food and non-food industries. Their use depends in the unique physicochemical properties that they provide, often at costs below those of synthetic polymers.

Diospyros melonoxylon Roxb a small tree with rather slender stem and smooth grey bark belonging to family Ebenaceae. Earlier, toxicological evaluation of seed mucilage of Diospyros melonoxylon Roxb. was carried out so as to enable its use as a food additive (Singh, Bothra, 2012). An understanding of the physico-chemical properties and structural characterization of mucilage is essential in exploiting its potential as a food additive and for other industrial applications.
Present investigation was undertaken to determine morphological, physicochemical and elemental analysis, of the mucilage of seed of Diospyros melonoxylon Roxb In order to provide a separate identity to this tree gum. The methods employed for the analysis include (i) particle size analysis by Microtrac $\AA$, (ii) scanning electron microscopy (SEM), (iii) gel permeation chromatography (GPC), dilute solution viscosity at different temperature using Brookfield viscometer, (iv) differential scanning calorimetry (DSC), (v) deferential thermal analysis (DTA), (vi) thermogravimetry analysis (TGA), (vii) zeta potential by zetatrac, (viii) elemental analysis (carbon (C), hydrogen $(\mathrm{H})$, nitrogen $(\mathrm{N})$ and sulfur $(\mathrm{S})$ ), (ix) mineral analysis, (x) X-ray diffraction spectrometry (XRD), (xi) Fourier transform infrared spectroscopy (FT-IR), (xii) 1D nuclear magnetic resonance (NMR) and (xiii) paper chromatography analysis.

\section{MATERIAL AND METHODS}

\section{Material}

Fruits of Diospyros melonoxylon Roxb. were collected from the forest of Rajgamar, District Korba, Chhattisgarh in the month of April-June and authenticated by Prof. H. B. Singh, NISCAIR, New Delhi, India. The seeds were separated and dried in ambient condition under shed. Mucilage was isolated from the seeds using maceration techniques and stored in airtight, desiccated polypropylene jars. De-ionized water was used for all experiments. All other chemicals used were of analytical reagent grade.

\section{Determination of particle size by particle size analyzer}

Particle size was determined by particle size analyzer (Zetatrac ${ }^{\circledR}$, Microtrac ${ }^{\circledR}$, NPA152-31A). Dispersion of sample was prepared in Water and $0.1 \mathrm{~N}$ $\mathrm{NaCl}$ and requisite information of the solvent like, density, viscosity, dielectric constant etc., were comprehended in the software (Zetatrac $\AA$, Microtrac ${ }^{\circledR}$-FLEX Software NPA152-3LA). About $3.0 \mathrm{~mL}$ sample dispersion were added in sample holder, made of optical probes paired with opposite electrodes in an insulating sample cell. An electric field was applied between the optical probes and their corresponding electrodes. Particle in motion analyzed under the influence of electric field. Particle size distribution was determined from the velocity distribution of particles suspended in a dispersing medium, using the principles of dynamic light scattering (Singh et al., 2009). 


\section{Scanning electron microscopy}

Appropriate samples were mounted on an aluminum stub with double-sided adhesive tape. The tape was first firmly attached to the stub and the sample powder was scattered carefully over its surface. The stub with the sample was then coated with a thin layer of gold to make the sample conductive. The photo micrographic processed specimen were obtained in SEM (Philips, Lancashire, XL 30) (Elijah, Barbara, 2010).

\section{Molecular weight by gel permeation chromatography}

Gel permeation chromatography (GPC, Waters Alliance 2695) was carried out to estimate molecular weight of the mucilage relative to dextran polysaccharide as standard, using Waters Alliance model coupled with Waters 2414 Refractive Index detector (RI). Mobile phase was $0.2 \mathrm{M} \mathrm{NaNO}_{3}$ in water at a flow rate of $1.0 \mathrm{~mL} / \mathrm{min}$, Ultrahydragel 500 and Ultrahydragel 120 $(7.8 \mathrm{~mm} \times 30 \mathrm{~cm} \times 9 \mu \mathrm{m})$ was in series. Detector and column was operated at $30^{\circ} \mathrm{C}$, which was started from $\mathrm{M}_{\mathrm{w}}$ : 5,$200 ; 48,600 ; 2,03,000 ; 6,68,000 ; 14,00,000$ Daltons. Spectra was processed using empower software.

\section{Determination of viscosity}

Rheological studies of mucilage in water were carried out at various temperatures. The viscosities of all mucilages were measured using Brookfield viscometer (Price, 1995).

\section{Differential scanning calorimetry}

Differential Scanning Calorimetry (DSC) analysis for mucilages was performed using a differential scanning calorimeter (Mettler Toledo Star System). Weighed amount of $(5 \mathrm{mg})$ samples was placed into platinum cups and sealed. The temperature range was from $0{ }^{\circ} \mathrm{C}$ to $300^{\circ} \mathrm{C}$ under Nitrogen atmosphere at a heating rate of $10^{\circ} \mathrm{C} / \mathrm{min}$ (Price, 1995).

\section{Differential thermal analysis}

Differential Thermal Analysis (DTA) is a very popular thermal analysis technique it measures endothermic and exothermic transitions as a function of temperature. The analysis of mucilage was performed on differential thermal analysis (Linseis Germany, Stapt-1600) in which accurately weighed $5 \mathrm{mg}$ samples were placed into platinum cups and sealed. The temperature range was from $0{ }^{\circ} \mathrm{C}$ to $240{ }^{\circ} \mathrm{C}$ at a heating rate of $15^{\circ} \mathrm{C} / \mathrm{min}$ (Stopic, Ilic, Uskokovic, 1997; Soumen et al., 2010).

\section{Thermogravimetry analysis}

The thermal analysis of mucilages was done using thermal analyzer (Linseis Germany, Stapt-1600) in which accurately weighed $15 \mathrm{mg}$ samples were placed into platinum cups and sealed. The temperature range was from 0 to $900{ }^{\circ} \mathrm{C}$ at a heating rate of $15^{\circ} \mathrm{C} / \mathrm{min}$.

\section{Electrokinetic studies; zeta potential}

Zeta Potential (ZP) was determined using Zetatrac (Microtrac, NPA152-31A) by measuring the response of charged particles to an electric field. In a constant electric field particles float at a constant velocity. Through the velocity, and charge and zeta potential can be determined. Zetatrac utilizes a high frequency AC electric field to oscillate the charged particles. The Brownian motion power spectrum is analyzed with the nanotrac controlled reference technique of particle sizing to determine the modulated power spectrum (MPS). This is a component of the power spectrum resulting from the oscillating particles. $\mathrm{ZP}$ was calculated for mucilage from the MPS signal using formula (Vinod et al., 2008) in water and $\mathrm{pH}$ dependence of the zeta potential was investigated with the background electrolyte of $0.1 \mathrm{~N} \mathrm{NaCl}$.

$$
\zeta=\mu \eta / \varepsilon
$$

where $\zeta=$ zeta potential, $\mu=$ mobility, $\eta=$ viscosity, $\varepsilon=$ dielectric constant, for water at $25^{\circ} \mathrm{C}$, Zeta potential $(\mathrm{mV}) \sim 12.8 \times$ Mobility $(\mu / \mathrm{sec} /$ volt $/ \mathrm{cm})$.

\section{Elemental composition (CHNS) and heavy metal analysis of mucilage}

Elemental compositions (CHNS) were analyzed using elemental analyzer (Elemental, Vario). Accurately weighed $0.5 \mathrm{~g}$ of sample was heated to $1150^{\circ} \mathrm{C}$ and corresponding element was determined by using elemental analyzer (Jeevanandham et al., 2010; Shlomo, Alfred, 1981; Niharika, Padmavati, Satyahari, 2010).

\section{Powder X-ray diffraction pattern}

Powder X-ray diffraction (PXRD) patterns of mucilage were recorded using X-ray diffractometer (Goniometer, BI-200SM). The experiments were carried 
out at $25^{\circ} \mathrm{C}$ : voltage and current were kept constant at $40 \mathrm{Kv}, 30 \mathrm{~m}$. A respectively. The X-ray diffraction at an angle of $2 \theta$ with a scan step time of $10.33 \mathrm{~s}$ for a specific length of $10 \mathrm{~mm}$ (Soumen et al., 2010).

\section{Fourier transform analysis}

Fourier Transform Analysis (FTIR) spectra of mucilage were recorded on a FT-IR spectrometer (Thermo Scientific). The dry powder was mixed with $\mathrm{KBr}$ and pressed into pellets under mechanical pressure. The FT-IR spectra were obtained by scanning between 4000 and $400 / \mathrm{cm}$.

\section{D nuclear magnetic resonance}

NMR spectra of ${ }^{1} \mathrm{H}$ and ${ }^{13} \mathrm{C}$ of mucilage were recorded in an NMR (400 MHz) spectrometer (Bruker Advance II $400)$. The test mucoadhesive agent $(100 \mathrm{mg}$ ) was dissolved in $\mathrm{D}_{2} \mathrm{O}$ and chemical shifts were reported in ppm relative to an internal standard TSP (3-trimethylsilylpropionic2,2,3,3,- $\mathrm{d}_{4}$ acid, sodium salt, $98 \%$ D) for ${ }^{1} \mathrm{H}$ NMR and 1,4-dioxane (d $66.67 \mathrm{ppm}$ ) for ${ }^{13} \mathrm{C}$ spectra. Proton NMR spectra was obtained at a base frequency of $400 \mathrm{MHz}$, with 16 transitions and delay time $1.5 \mathrm{~s}$ and for ${ }^{13} \mathrm{C}$, the base frequency was $100 \mathrm{MHz}$, with 3000 scans and delay time 2 s (Mihaela et al., 2008; Pablyana et al., 2009; Anderson, Wang, 1990).

\section{Sugar composition by paper chromatography}

Carbohydrate or sugars occupy a central position in plant metabolism, so the method of their detection and estimation are very important. Sugars are conveniently classified into three groups, on the basis of molecular size: the simple monosaccharide's (e.g. glucose, fructose) and their derivatives; the oligosaccharides, from by condensation of two or more monosaccharide's units (e.g. sucrose); and the polysaccharides which consist of long chains of monosaccharide's units, joined head to tail, either as straight chains or without branching. The samples were hydrolyzed and prepared in distilled water for paper chromatography. The paper chromatography analysis was performed using n-Butanol: acetic acid: water $(4: 1: 1)$ as solvent system with using arabinose, fructose, mannose, rhamnose and xylose as reference standard.

\section{RESULTS AND DISCUSSION}

\section{Particle Size Analysis}

The average particle size as determined by Zetatrac particle size analyzer indicated that particle were in fine and smooth in appearance. The particle average size was obtained as $4030 \mathrm{~nm}$ diameter. The results showed that, the dried powder mucilage have flow properties which could be suitable for the use of wet granulation technology. Particle size also previews the degree of densification, which could occur during tableting which was further confirmed by particle size analysis.

\section{Scanning electron microscopy}

Scanning electron microphotographs (SEM) of mucilage obtained is represented in Figure 1 at different magnifications. The microphotographs of mucilages are indicative of an amorphous material. The particles are mostly seen as aggregates of irregular shapes and dimensions which were fibrous in nature. The SEM results of the present study suggest that, hydration capacity of mucilage depends on the surface property. The shape and structure or surface topography of the mucilage may be affected by the method of extraction and purification or preparation of the product (Qian et al., 2009). Wang, Ellis, Ross-Murphy (2002, 2003 and 2006) had reported that, particle size and specific surface area influence the hydration behavior of gums, which in turn influence their intrinsic viscosity and molecular mass. They also reported
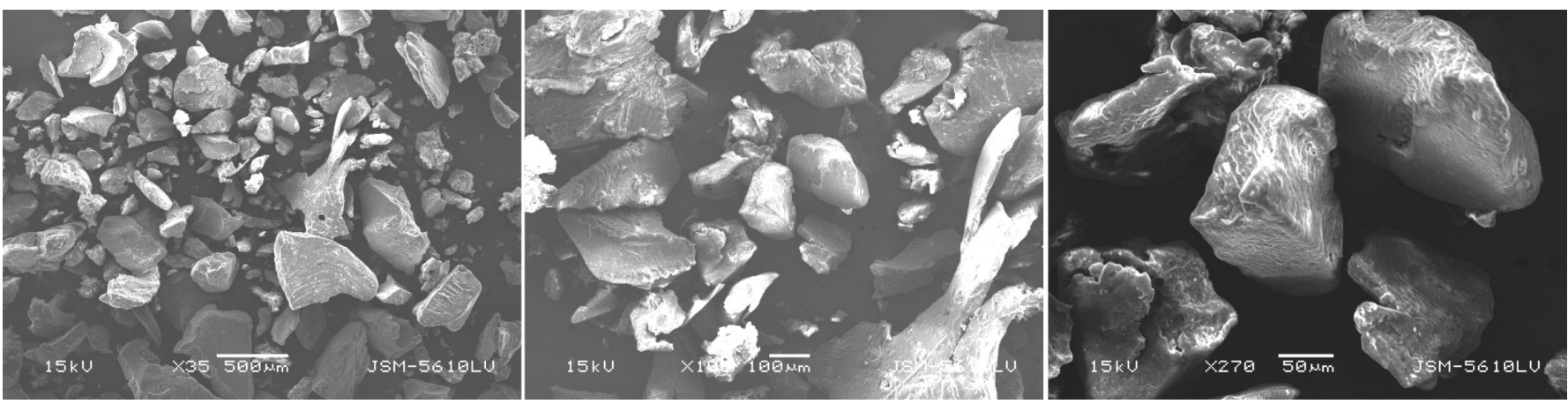

FIGURE 1 - Scanning electron microscopy of mucilage at different magnification using Philips, Lancashire, XL-30 SEM. 
that particle size influenced the hydration kinetics and molecular mass of Guar gum which is a galactomannanrich tree gum.

\section{Molecular weight by gel permeation chromatography}

Polymer molecular weight determination is important phenomena because it determines many physical properties such as the temperatures for transitions from liquids to waxes to rubbers to solids and also mechanical properties such as stiffness, strength, viscoelasticity, toughness, and viscosity. The molecular weight of mucilage was determined by gel permeation chromatography and expressed as the 'Dextran polysaccharide equivalent' molecular weight. The computed average molecular weights (Mw), number average molecular weight (Mn), and polydispersity $(\mathrm{Mw} / \mathrm{Mn})$ are tabulated in Table I. The polydispersity of isolated mucilage was obtained as 1.45. The polydispersity index $(\mathrm{Mw} / \mathrm{Mn})$ is used as a convenient measure of the range of molecular weight present in a distribution and is in the range of 1.4-6.0 for natural polysaccharide gums. If molecular weight is too low, the transition temperatures and the mechanical properties will generally be too low for the polymer material to have any useful commercial applications. For a polymer to be useful it must have transition temperatures to waxes or liquids that are above room temperatures and it must have mechanical properties sufficient to bear design loads.

\section{Determination of Viscosity}

The viscosity studies of $1.0 \% \mathrm{w} / \mathrm{v}$ solution for isolated mucilage at different temperatures showed decrease in viscosity with increase of temperature. The result of viscosity indicated that mucilage required structural modification as viscosity is not too high to suite specific novel dosage form.

\section{Differential scanning calorimetry and differential thermal analysis}

DSC has emerged as powerful physical tools to monitor physical and chemical changes that occur in the gum during thermal processing and these methods yield curves that are unique for a given gum. The outcome of differential scanning calorimetry (DSC) analysis of mucilage revealed the glass transition temperature is $78^{\circ} \mathrm{C}$. The major intense peak recorded in the DSC thermograms is an endothermic transitions (at around $200{ }^{\circ} \mathrm{C}$ ) followed by weaker exotherm(s). The DSC endotherm is presented in Figure 2. The result of differential thermal endotherm analysis is represented in Figure 3 for mucilage. The outcome of differential thermal analysis (DTA) analysis for mucilage reveals the transition temperature is $74{ }^{\circ} \mathrm{C}$. DSC and DTA is essentially a techniques that, compares the difference between the energy acquired or released by a sample and a suitable reference as a function of temperature or time while the sample and reference are subjected to a controlled temperature rise. The result of DSC and DTA revealed that, the isolated mucilage from seeds has good stability. Dehydration, depolymerization and pyrolitic decomposition are involved in DSC and DTA at high temperature stages resulted in the formation of $\mathrm{H}_{2} \mathrm{O}, \mathrm{CO}$ and $\mathrm{CH}_{4}$. However, because of the difference in structures and functional groups, either the degradation routes or the resulting fragments will be different. Most of the polysaccharides are comprised of carboxylate or carboxylic acid functional groups. Therefore, thermal scission of the carboxylate groups and evolution of $\mathrm{CO}_{2}$ from the corresponding carbohydrate backbone may be a probable mechanism for the thermal transitions. Accurate assigning of the thermal transitions is very difficult (Zohuriaan, Shokrolahi, 2004).

\section{Thermogravimetry analysis}

For a polymer research, the Thermogravimetry analysis TGA is especially suited to determine residual solvent, residual monomer and the released components in the earliest stage of a thermal degradation process (Nita, Aurica, 2011). TGA is a simple and accurate method for studying the decomposition pattern and the thermal stability of polymers. Table II gives the details of thermal behavior according to the primary thermograms and derivative thermograms of mucilage. The representative plot results of thermo-gravimetric analysis carried out on the mucilage's under lean oxygen ( $5 \%$ oxygen in nitrogen) atmosphere are shown in Figure 4. The details of thermal behavior and thermal stability data according to the primary

TABLE I - Gel permeation chromatography characterization of mucilage

\begin{tabular}{lccccccc}
\hline Polymer & Mn & Mw & Mp & Mz & Mz + 1 & Polydispersity & Mw/ Mn \\
\hline Mucilage & 3561 & 5299 & 7207 & 7240 & 8760 & 1.488143 & 1.45138 \\
\hline
\end{tabular}




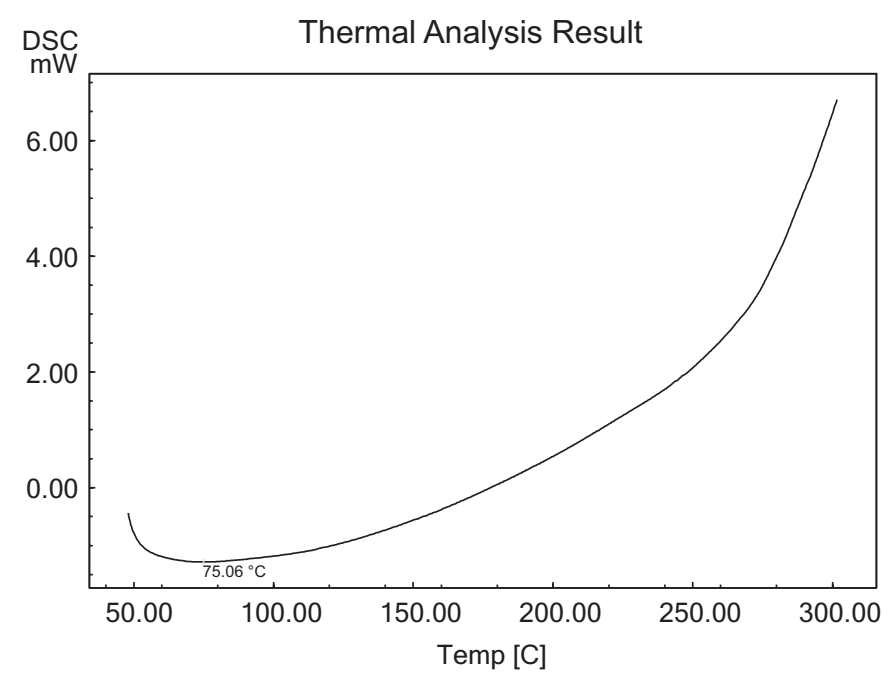

FIGURE 2 - Differential Scanning Calorimetry (DSC) Characterization of mucilage Using DSC analyzer.

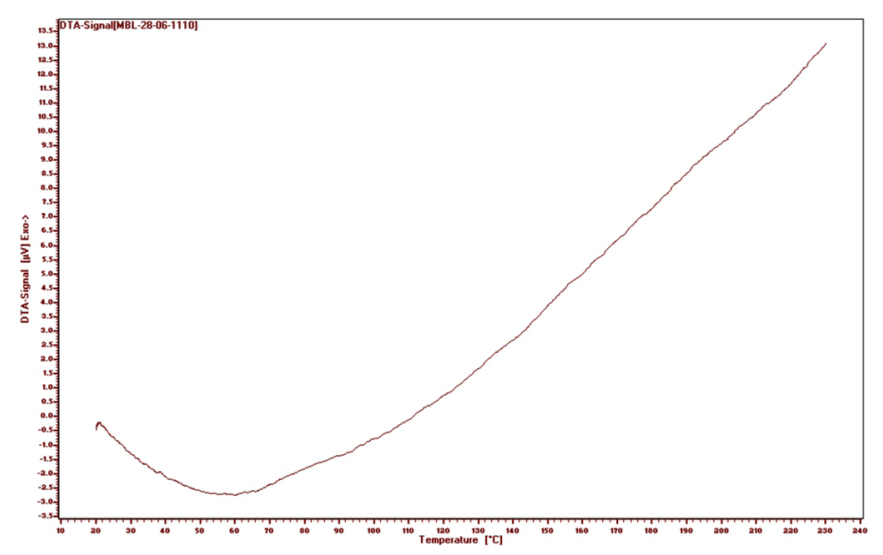

FIGURE 3 - Differential Thermal Analysis (DTA) Characterization of mucilage Using DTA Analyzer.

thermograms and derivative thermograms for the gum showed that heating at a rate of $10^{\circ} \mathrm{C}$ per minute from $0{ }^{\circ} \mathrm{C}$ to a maximum of $900{ }^{\circ} \mathrm{C}$ resulted in three mass loss events. Thermogravimetry analysis of mucilage showed three stages of decomposition. The early minor weight loss in samples is attributed to the loss of adsorbed and structural water of biopolymers as explained by other authors (Vendruscolo et al., 2009; Kittur et al., 2002), or due to desorption of moisture as hydrogen bound water to the saccharide structure. The second weight loss event may be attributed to the polysaccharide decomposition (Zohuriaan, Shokrolahi 2004; Varma et al., 1997) and is described by a weight loss. The weight loss onset representing the onset of oxidation or decomposition of polymer suggests that mucilage's have good thermal stability.

\section{Elemental composition (CHNS) and heavy metal analysis of mucilage}

Elemental analysis is a process where a sample of some material (e.g., soil, minerals, chemical compounds) is analyzed for its elemental composition such as carbon, hydrogen, nitrogen and sulphur. Elemental analysis can be qualitative (determining what elements are present), and even it can be quantitative. The result of Elemental composition and Heavy Metal Characterization are tabulated in Table III. The elemental analysis study showed that the isolated mucilage had certain percentage of carbon, nitrogen, sulphur and hydrogen while toxic heavy metal like arsenic, lead, cadmium and mercury were absent. The present study indicated similar compositions of element as reported earlier for gum Kondagogu by Vinod et al., (2008). The presence of nitrogen may indicate the presence of protein in the sample. Further, study also suggested the presence of S-containing protein and amino acids, also confirms the formation of bond (primary strong covalent bonds, weak secondary hydrogen bond and Vander Waal's forces) of mucilage with mucosa in a short duration of time.

\section{Electrokinetic studies (Zeta Potential)}

The electrokinetic behavior depends on the potential between the surface and the electrolyte solution. Electrokinetic measurement is one way to study complex surface chemical exchange-processes at the mineral surface/liquid interface. All electrokinetic phenomena are related to the development of electrical double layer at the particle/electrolyte interface. The ZP is defined as the potential of shear plane of the particle when it moves in liquid. ZP was measured to collect information on

TABLE II - Thermogravimetry analysis of mucilage

\begin{tabular}{|c|c|c|c|c|c|c|}
\hline Polymer & $\begin{array}{c}\text { Decomposition } \\
\text { stage }\end{array}$ & $\begin{array}{l}\text { Temperature } \\
\text { range }\left({ }^{\circ} \mathbf{C}\right)\end{array}$ & $\begin{array}{c}\text { DTG Peak } \\
\left({ }^{\circ} \mathrm{C}\right)\end{array}$ & $\begin{array}{c}\text { Enthalpy } \\
(\mathrm{J} / \mathrm{g})\end{array}$ & $\begin{array}{c}\text { Heat Change } \\
(\mu \mathrm{Vs} / \mathrm{mg})\end{array}$ & $\begin{array}{c}\text { \% Weight } \\
\text { loss }\end{array}$ \\
\hline \multirow{3}{*}{ Mucilage } & 1 & $221.2-334.7$ & 70.1 & -177.720 & -54.4931 & 36.57 \\
\hline & 2 & $334.7-394.3$ & 304.7 & 225.8651 & 109.3868 & 6.64 \\
\hline & 3 & $394.3-563.3$ & 475.4 & 7641.322 & 2483.341 & 31.99 \\
\hline
\end{tabular}



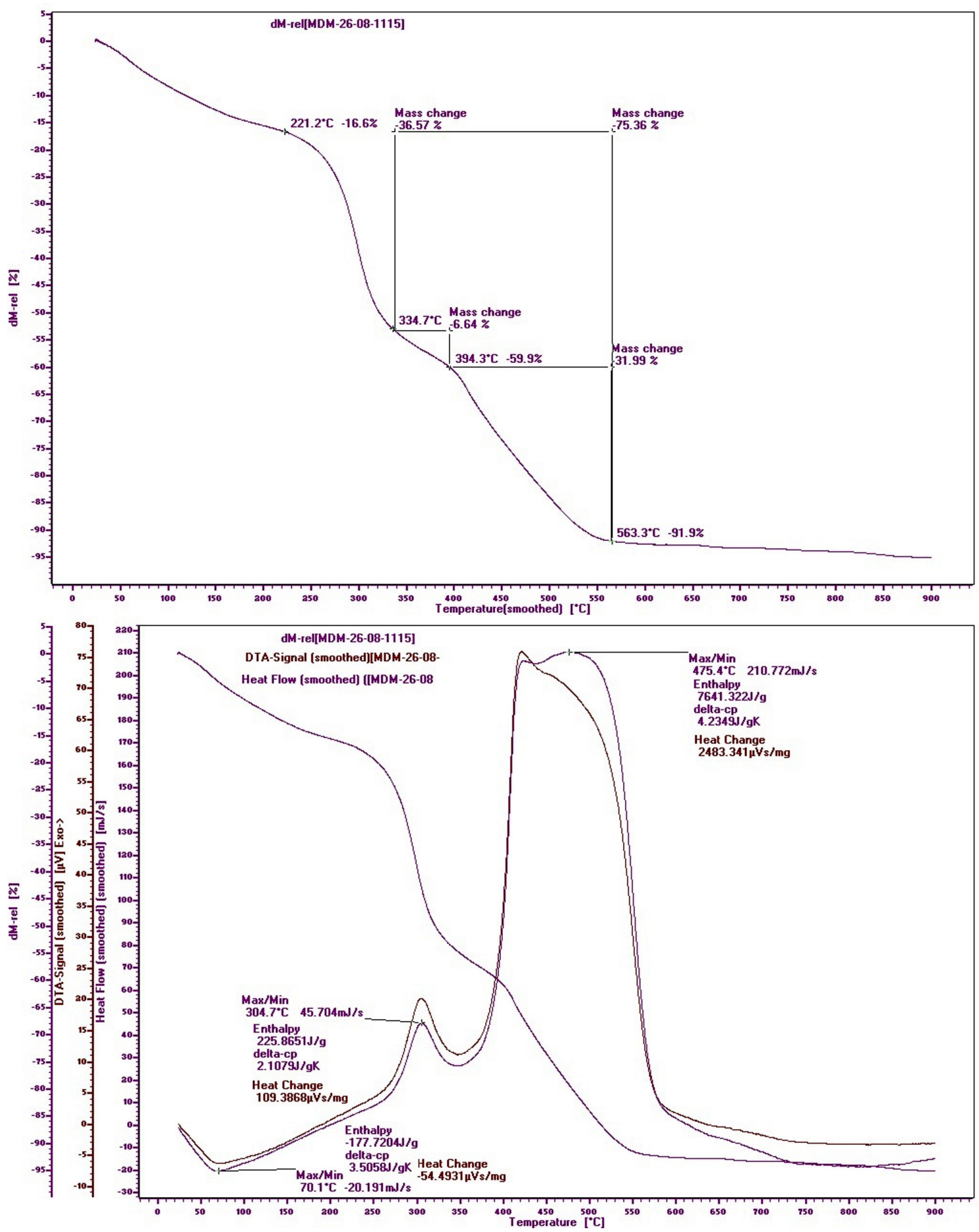

FIGURE 4 - Thermogravimetry analysis characterization of mucilage using TGA analyzer.

TABLE III - Elemental composition and heavy metal characterization of mucilage

\begin{tabular}{lccccccccc}
\hline Polymer & $\mathbf{C ~ ( \% )}$ & $\mathbf{H}(\%)$ & $\mathbf{N}(\%)$ & $\mathbf{W}_{\mathrm{C} / \mathbf{N}}$ & $\mathbf{S ~ ( m g / k g )}$ & Arsenic & Lead & Cadmium & Mercury \\
\hline Mucilage & 78.8 & 12.2 & 0.634 & 124.29 & 681 & ND & ND & ND & ND \\
\hline
\end{tabular}

ND: Not detectable 
the stability and charge behavior of the polymer. The $\mathrm{ZP}$ of mucilage in aqueous medium and in $0.1 \mathrm{~N} \mathrm{NaCl}$ were recorded and found to be $5.90 \mathrm{mV}$ and $4.65 \mathrm{mV}$ respectively. The results of $\mathrm{ZP}$ studies suggested that, the mucilage is ionic in nature and attributed to the presence of uronic acids as similar to previously reported by Mohammadifar et al., (2006) for gum tragacanth which is also uronic acid-rich gum. Polarity of mucilage may be due to the presence of -OH group, which are readily available for the formation of hydrogen bonds on the interface of reinforced systems. However, plant mucilage is covered with pectin and waxy substances, thus hindering the hydroxyl groups (-OH) from reacting with polar matrices and deteriorate adhesion, but polar structure is only responsible for hydrophilic behavior of mucilage. Further the results indicated that mucilage swells strongly in an aqueous environment. For high adhesion forces it is necessary to have polar functional groups, but swelling processes should be hindered. The extent of mucus adsorption is proportional to the absolute values of the positive zeta potential of mucilage and negative ' $\mathrm{ZP}$ ' of mucus glycoprotein (Ping et al., 1998). Shashikant, Sudhir, Avinash, (2009) also reported that, the significant difference in $\mathrm{ZP}$ of a polymer may be obtained due to change in environment i.e. particles decomposition which yield small charge and surface properties of particles. Further, the electrophoretic mobility of suspended particle depends on zeta potential. It was concluded that, therefore conductivity of any solution is a function of electrolytes or ions and charge in ionic concentration is known to increase conductivity. The conductivity and dielectric constant often increase with thermal and electrical stress. These changes are indicative of decomposition of material to yield few smaller molecules. Also findings support the fact that, there is concomitant shift in UV and IR Spectra. Taking account of earlier studies it can be ascertained that the ZP caused huge impact on properties of mucilage.

\section{Powder X-ray diffraction pattern}

The powder X-ray diffraction is a useful method for investigating the arrangement of atom and molecules within the material. If there is an orderly arrangement of substructure within the material with repeat distances of a similar magnitude to the wavelength of light used interference patterns are produced, and such patterns provide information on geometry of polymer structure. Powder XRD (PXRD) analysis of mucilage is shown in Figure 5. The results indicated that, there were no characteristic peaks in the spectrum, indicating that, the mucilage is completely amorphous in nature. Natural gums, such as Arabic, Guar gum and Karaya gum, also show amorphous nature (Malik, Gupta, Sarkar, 2002; Murali, Prasad, Ramana, 2002; Thimma, Shekharam, 2004).

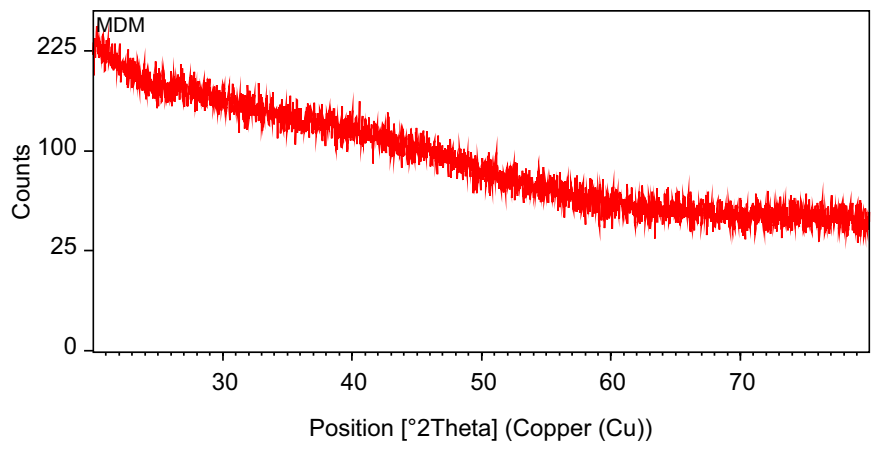

FIGURE 5 - Powder X-ray diffraction spectra of mucilage obtained from seeds of $D$. melonoxylon using goyenimeter.

\section{Fourier transform analysis}

FTIR spectrometry has been extensively applied to characterize the polymer's molecular and material structure. Characterization using FTIR spectroscopy often results in the identification of functional groups and the modes of their attachment to polymer backbone (Baxter et al., 1992). The FTIR spectra exhibit the typical bands and peak characteristic for mucilage. The FT-IR spectrum of mucilage is presented in Figure 6. 'CHEMIX' School software was used to interprete. Spectra exhibited the typical bands and peak characteristic of polysaccharides. The spectra of mucilage shows band occurring at $3556.89 \mathrm{~cm}^{-1}$ results from the presence of amide $\mathrm{N}-\mathrm{H}$ and $\mathrm{C}=\mathrm{O}$ stretch and amine $\mathrm{N}-\mathrm{H}$. The peak obtained at $3447.91-3354.35 \mathrm{~cm}^{-1}$, results from the presence of hydroxyl (-OH and -CO) groups. The peak obtained at $2885.63-2811.37 \mathrm{~cm}^{-1}$ results from stretching modes of the alkyl C-H stretch, carboxylic acid $\mathrm{C}=\mathrm{O}$ and $\mathrm{O}-\mathrm{H}$ stretch and methylene $\left(-\mathrm{CH}_{2}-\right) \mathrm{C}-\mathrm{H}$ stretch. The peak obtained at $2161.33-1666.57 \mathrm{~cm}^{-1}$ results from stretching mode of the alkenyl $\mathrm{C}-\mathrm{H}$ and $\mathrm{C}=\mathrm{C}$ stretch, amide $\mathrm{N}-\mathrm{H}$ and $\mathrm{C}=\mathrm{O}$ stretch. The broad band occurring at $3500-3200 \mathrm{~cm}^{-1}$, results from the presence of hydroxyl $(-\mathrm{OH})$ groups. The peak obtained at $2885-2705 \mathrm{~cm}^{-1}$ results from stretching modes of the $\mathrm{C}-\mathrm{H}$ bonds of methyl groups $\left(-\mathrm{CH}_{3}\right)$. Natural gums usually contain fractions of sugar acid units which would usually impart a weakly anionic character to the gum macromolecule (Wang, Ellis, Ross-Murphy, 2003). Absorption bands around 1618 and $1430 \mathrm{~cm}^{-1}$ are typical of carboxylate groups of the galacturonic acid residues as reported by Okafor, Chukwu, Udeala, (2001) and Figueiro et al., (2004). The region between 1500 and $1800 \mathrm{~cm}^{-1}$ is typically used to detect presence of carboxylic groups. 


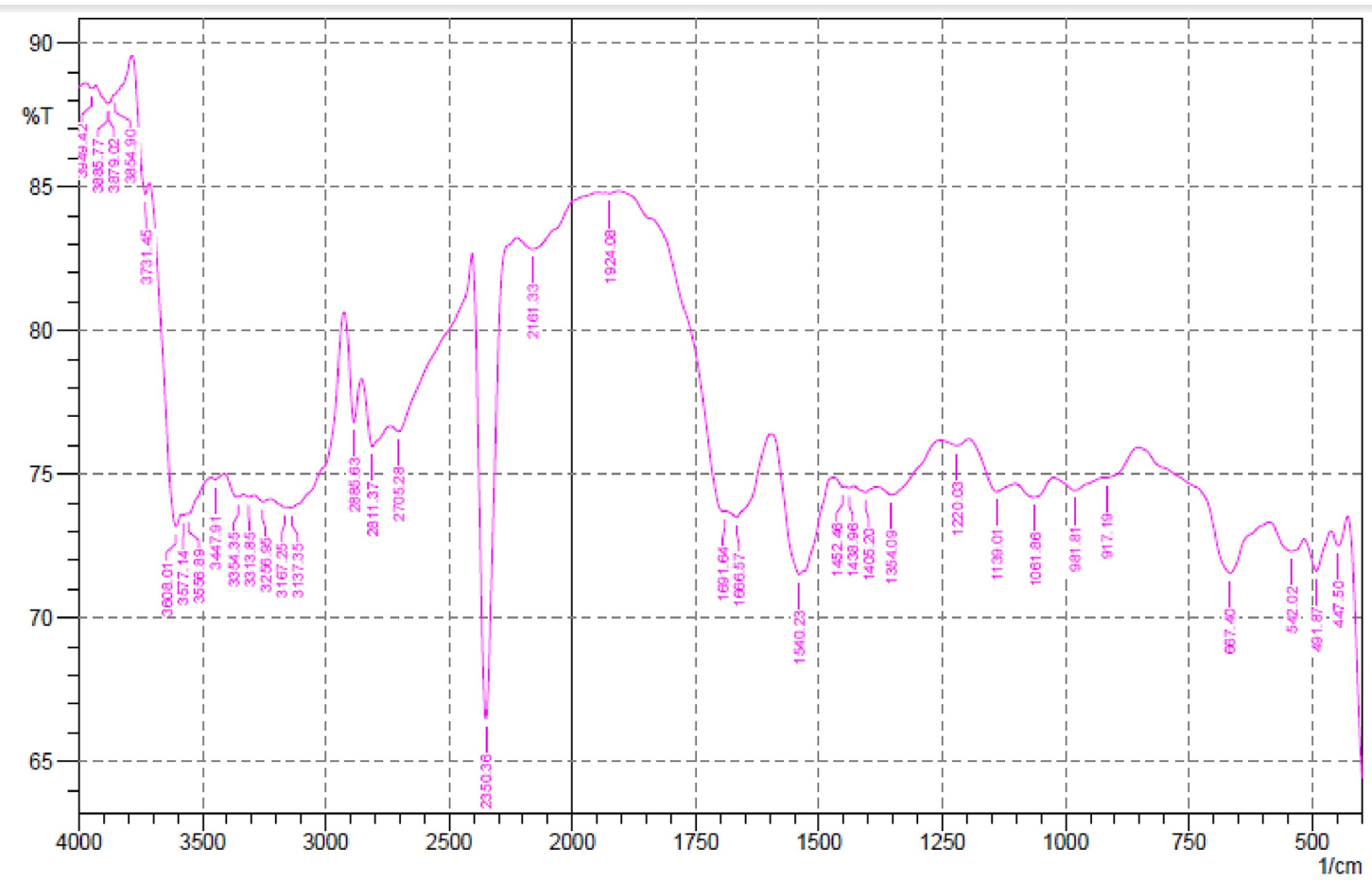

FIGURE 6 - FTIR spectral characterization of mucilage using thermo scientific FTIR spectrophotometer.

Also absorption peaks at $1740 \mathrm{~cm}^{-1}$ and $1258 \mathrm{~cm}^{-1}$ are typical of acetyl groups (Xiaodong, Marek, 2007). The wave numbers between 800 and $1200 \mathrm{~cm}^{-1}$ represents the finger print region for carbohydrates.

\section{D Nuclear Magnetic Resonance}

NMR is a most powerful tool for study of microstructure and chain configuration of polymers, both in solution and in solid state. The importance of NMR as a technique from the fact that NMR signals can be assigned to specific atoms along the polymer backbone and side chains. The NMR spectra of ${ }^{1} \mathrm{H}$ and $\mathrm{C}^{13}$ were interpreted using CHEMIX School software, which are shown in Figure 7 and 8. Spectra exhibit the typical bands and peak characteristic of polysaccharides. The ${ }^{1} \mathrm{H}$ and $\mathrm{C}^{13}$ NMR spectra of mucilage indicated certain sugar composition such as signals of ${ }^{1} \mathrm{H}$ NMR signals between $\delta 3.65-\delta 3.60 \mathrm{ppm}$ can be attributed to $\mathrm{OH}$ and $\mathrm{CH}$ group of mannose. The signals between $\delta 3.81-\delta 3.55 \mathrm{ppm}$ can be attributed to $\mathrm{CH}_{2}$ group of arabinose. The signal at $\delta 72.2$ ppm of $\mathrm{C}^{13} \mathrm{NMR}$ spectra can be attributed to $\mathrm{CH}$ group of rhamnose. The signal at $\delta 72.3 \mathrm{ppm}$ of $\mathrm{C}^{13} \mathrm{NMR}$ spectra can be attributed to $\mathrm{CH}$ group of mannose. The signals ranging from $\delta 70.1-\delta 71.8 \mathrm{ppm}$ can be attributed to $\mathrm{CH}$ group of arabinose. The ${ }^{1} \mathrm{H}$ NMR spectrum for mucilage showed few singlet's at high field $(\delta 1.19 \mathrm{ppm}(\mathrm{s})$, $\delta 1.96 \mathrm{ppm}(\mathrm{s})$ ), which is related to the environments of methyl groups of rhamnose and the protons linked to C-6 $(\delta 3.65, \delta 3.70 \mathrm{ppm})$ and $\mathrm{C}-4$ of galactose $(\delta 3.98$, $4.28 \mathrm{ppm})$, respectively, and this suggests the existence of different galactose derivatives (Agrawal, 1992; Vogt, Stephen, Jackson, 1990). The anomeric protons have been assigned to $\beta$-sugar residues ( $\mathrm{d} 4.92-4.96 \mathrm{ppm}$ ) and the $\alpha$-sugar residue ( $\delta 5.1-5.3 \mathrm{ppm})$, as reported earlier by Agrawal, (1992); Vogt, Stephen, Jackson, (1990). The two closely neighbored signals observed in the ${ }^{1} \mathrm{H}$ NMR spectrum of mucilage ( $\delta 4.02$ and $\delta 3.84 \mathrm{ppm})$ were assigned to H-1 of a-glucose (Samuelson et al., 1998). The ${ }^{1} \mathrm{H}$ NMR spectrum showed that crowded narrow region between 3 to $5 \mathrm{ppm}$ typical of polysaccharides and confirms the presence of many similar sugar residues (Xiaodong, Marek, 2007). The signals between 3.1 to $4.3 \mathrm{ppm}$ can be assigned to non-anomeric protons $\left(\mathrm{H}_{2}-\mathrm{H}_{6}\right)$ while signals between 4.3 to 4.8 , and 4.9 to $5.5 \mathrm{ppm}$ arise from $\alpha$-anomeric and $\beta$-anomeric protons respectively. ${ }^{13} \mathrm{C}$ NMR spectra of mucilages gave line widths which are typical of an amorphous natural polymer with broad band signals. There are resonance spectra due to the methyl group of rhamnose ( $\delta 16.67 \mathrm{ppm})$ as reported earlier by Martinez et al., (1996).

\section{Sugar composition by paper chromatography}

Plant gums and mucilage are an important group of plant constituents with pharmaceutical and technical 


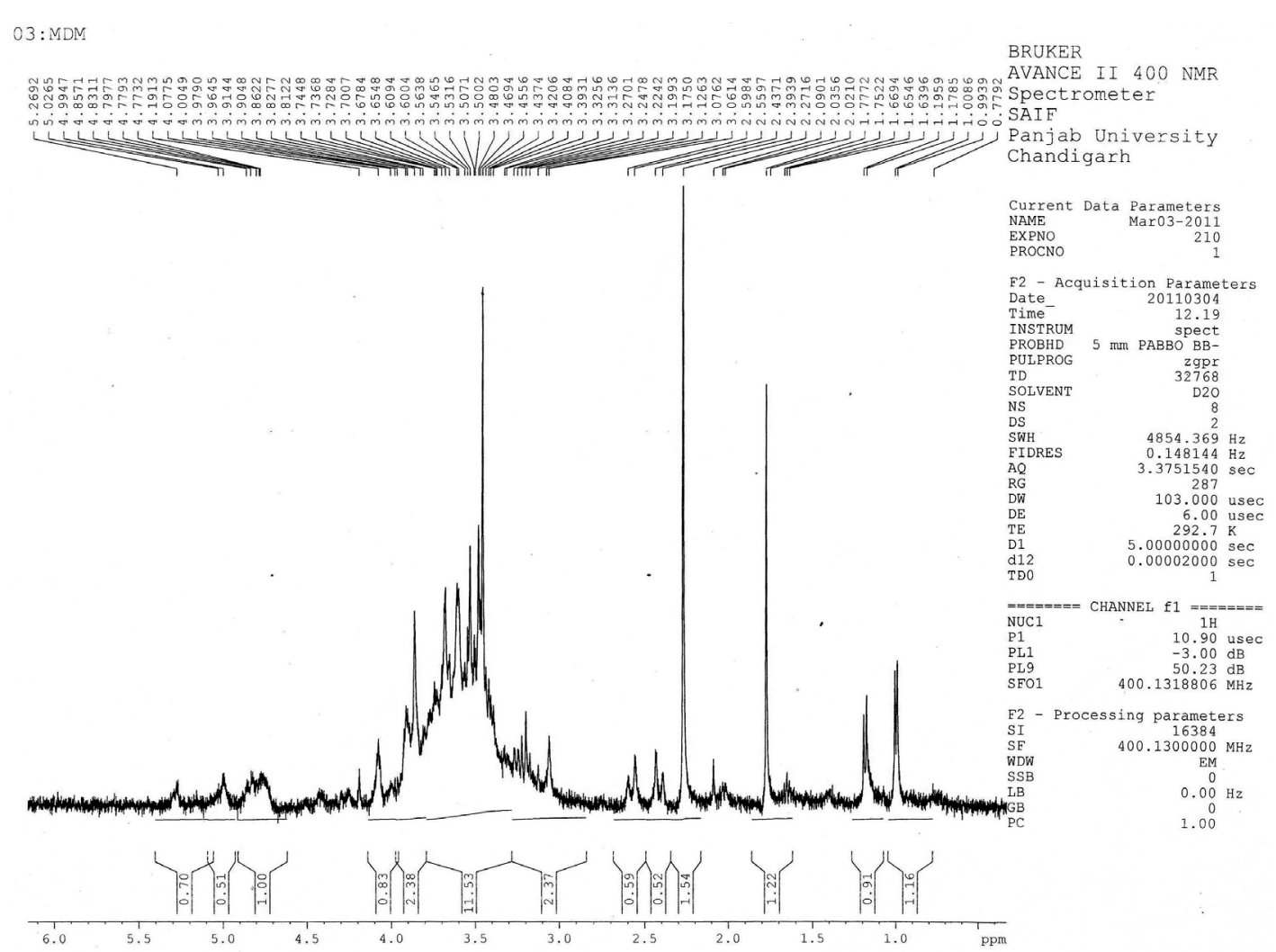

FIGURE 7 - 1D ${ }^{1} \mathrm{H}$ NMR Spectral characterization of mucilage using bruker advance II 400 NMR spectrophotometer.

MDM
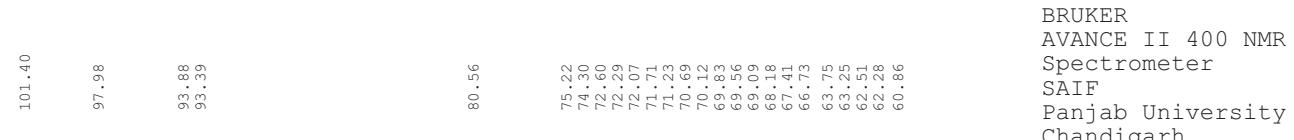

Chandigarh

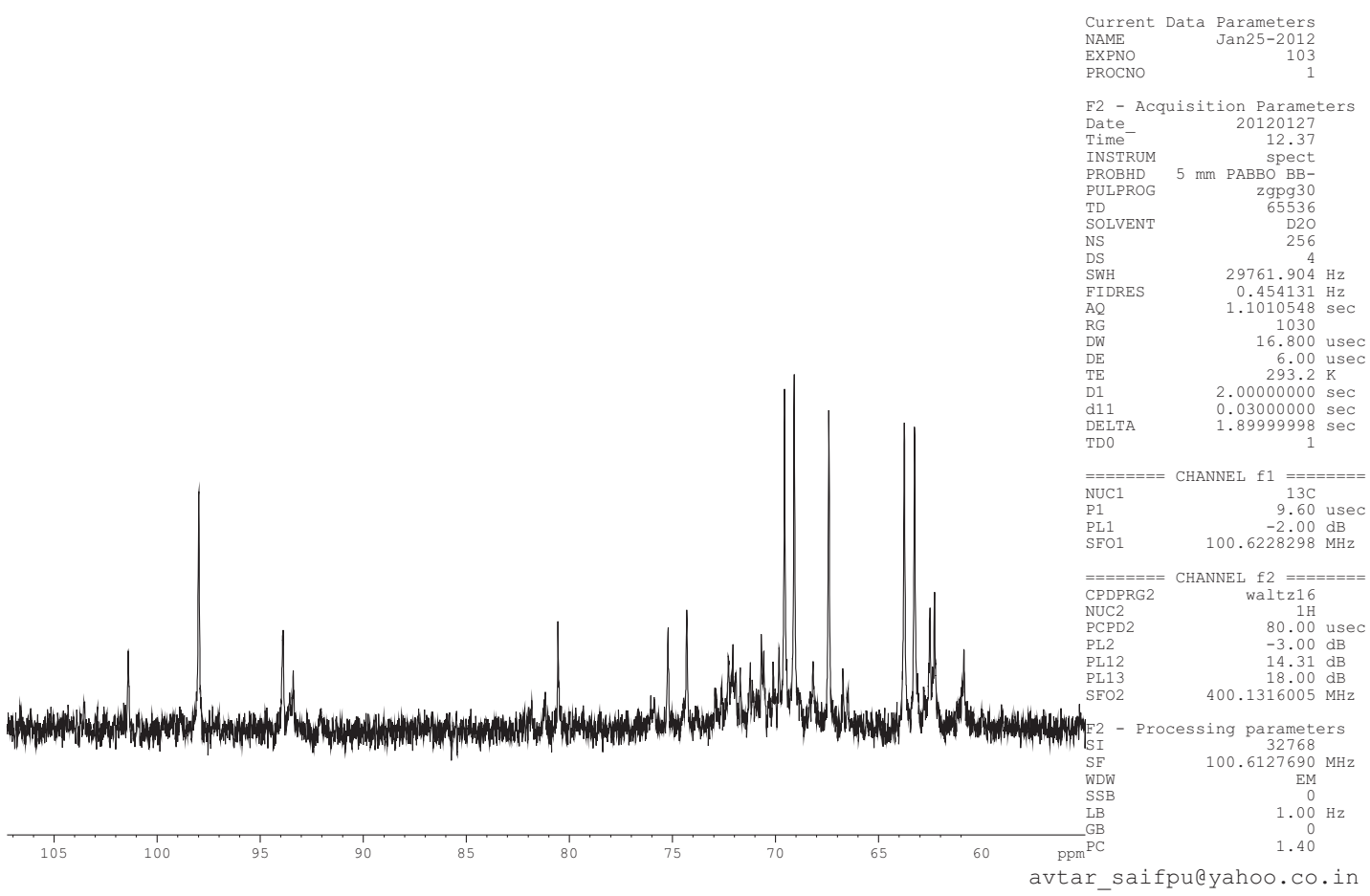

FIGURE 8 - 1D C ${ }^{13}$ NMR spectral characterization of mucilage using bruker advance II 400 NMR spectrophotometer. 
uses. The separation and sensitive determination of various carbohydrates is currently of great interest in nutrition, medical cell biology and biotechnology research. Carbohydrates are difficult to analyze because they are very polar compounds, exhibit similar structural characteristics, and do not have a suitable chromophore. The $R_{f}$ value of standards arabinose, fructose, mannose, rhamnose and xylose matched with the obtained $R_{f}$ values of test substances (mucilage). The result obtained from 1D NMR, FTIR and paper chromatography studies indicated the presence of arabinose, fructose, mannose, rhamnose, xylose and glucose. The results obtained from the study are corroborative of $\mathrm{R}_{\mathrm{f}}$ values of the standard sugars.

\section{CONCLUSIONS}

D. melonoxylon seeds mucilage is a novel polysaccharide gum with little published information on its characterization. It is a natural, biodegradable, non-toxic material and requires lower production cost. The overall findings of the study indicated that mucilage isolated from the seeds have an inherent property which can be used in various dosages forms. The PXRD and SEM revealed that mucilage is amorphous in nature which indicated that wet granulation technology could be suitable for dosage formulation. Significant mineral and elemental composition was obtained. The thermal stability study by DSC, DTA and TGA showed that, mucilage had good thermal stability. FTIR, solid $1 \mathrm{D}{ }^{1} \mathrm{H}$ and $\mathrm{C}^{13}$ NMR and paper chromatography confirmed presence of non-reducing sugars. All these results demonstrate that, mucilage is a useful pharmaceutical aid and can be used for effectively controlling the release of drugs from the designed matrix systems.

\section{REFERENCES}

AGRAWAL, P.K. NMR spectroscopy in the structural elucidation of oligosaccharides and glycosides. Phytochemistry, v.31, p.3307-3330, 1992.

ALONSO-SANDE, M.; TEIJEIRO, D., REMUNANLOPEZ, C.; ALONSO, M.J. Glucomannan, a promising polysaccharide for biopharmaceutical purposes. Eur. J. Pharm. Biopharm., v.72, p.453-62, 2009.

ANDERSON, D.M.W.; WANG, W. The characterization of Acacia paolii gum and four commercial acacia gums from Kenya. Food Hydrocolloid, v.3, p.475-484, 1990.
BAXTER, A.; DILLLON, M.; TAYLOR, K.D.A.; ROBERTS, G.A.F. Improved method for IR determination of the degree of N-acetylation of chitosan. Int. J. Biol. Macromol., v.14, p.166-169, 1992.

CHAMARTHY, S.P.; PINAL, R. Plasticizer concentration and the performance of a diffusion-controlled polymeric drug delivery system. Colloids Surfaces A: Physicochem. Eng. Aspect., v.331, p.25-30, 2008.

EFENTAKIS, M.; KOUTTIS, A. Release of Furosemide from multiple unit and single unit preparations containing different viscosity grade of sodium alginate. Pharm. Dev. Technol., v.6, p.91, 2001.

ELIJAH, I.N.; BARBARA, R.C. Characterization of grewia gum, a potential pharmaceutical excipient. J. Excipients Food Chem., v.1, p.30-40, 2010.

FIGUEIRO, S.D.; GOES, J.C.; MOREIRA, R.A.; SOMBRA, A.S.B. On the physicochemical and dielectric properties of glutaraldehyde cross-linked galactomannan-collagen films. Carbohydr. Polym., v.56, p.313-320, 2004.

GUO, J.; SKINNER, G.W.; HARCUM, W.W.; BARNUM, P.E. Pharmaceutical applications of naturally occurring water-soluble polymers. Pda. J. Pharm. Sci. Technol., v.1, p.254-61, 1998 .

JANI, G.K.; SHAH, D.P.; PRAJAPATI, V.D.; JAIN, V.C. Gums and mucilages: versatile excipients for pharmaceutical formulations. Asian J. Pharm. Sci., v.4, p.309-323, 2009.

JEEVANANDHAM, S.; SEKAR, M.; DHACHINAMOORTHI, D.; MUTHUKUMARAN, M.; SRIRAM, N.; JOYSARUBY, J. Sustained release of various drugs from Leucaena leucocephala polysaccharide. J. Young Pharm., v.2, n.1, p.15-20, 2010.

KITTUR, F.S.; HARISH PRASHANTH, K.V.; UDAYA SANKAR, K.; THARANATHAN, R.N. Characterization of chitin, chitosan and their carboxymethyl derivatives by differential scanning calorimetry. Carbohydr. Polym., v.49, p.185-193, 2002.

MALIK, H.; GUPTA, N.; SARKAR, A. Anisotropic electrical conduction in gum Arabic-A biopolymer. Mat. Sci. Eng. C, v.20, p.215-218, 2002. 
MARTINEZ, M.; LEON DE PINTO, G.; RIVAS, C.; OCANDO, E. Chemical and spectroscopic studies of the gum polysaccharide from Acacia macracantha. Carbohydr. Polym., v.29, p.247-252, 1996.

MIHAELA, H.; DESBRIERES, J.; KHOUKH, A.; POPA, M.; RIESS, G. Synthesis and characterization of new unsaturated esters of Gellan Gum. Carbohydr. Polym., v.71, p.92-100, 2008.

MOHAMMADIFAR, M.A.; MUSAVI, S.M.; KIUMARSI, A.; WILLIAMS, P.A. Solution properties of targacanthin (water-soluble part of gum tragacanth exudates from Astragalus gossypinus). Int. J. Biol. Macromol., v.38, p.31-39, 2006.

MURALI MOHAN BABU, G.V.; PRASAD, Ch.D.; RAMANA MURTHY, K.V. Evaluation of modified gum karaya as carrier for the dissolution enhancement of poorly watersoluble drug nimodipine. Int. J. Pharm., v.234, p.1-17, 2002.

NIHARIKA, S.; PADMAVATI, M.; SATYAHARI, D. Herbal drugs: standards and regulation. Fitoterapia, v.81, p.462$471,2010$.

NITA, T.; AURICA, P.C. TGA/FTIR/MS study on thermal decomposition of poly(succinimide) and sodium poly(aspartate). Polym. Test, v.30, p.397-407, 2011.

TUDORACHI, N.; CHIRIAC, A.P. TGA/FTIR/MS study on thermal decomposition of poly(succinimide) and sodium poly(aspartate). Polym. Test, v.30, p.397-407, 2011.

OKAFOR, I.S.; CHUKWU, A.; UDEALA, K. Some physicochemical properties of Grewia gum. Nigerian $J$. Polym., v.2, p.161-167, 2001.

PABLYANA, L.R.; CUNHA, ICARO, G.P.; VIEIRA, ANGELA, M.C.; ARRIAGA, PAULA DE, R.C. M.; JUDITH, P.A.; FEITOSA. Isolation and characterization of galactomannan from Dimorphandra gardneriana Tul. Seeds as a potential guar gum substitute. Food Hydrocolloid, v.23, p.880-885, 2009.

PANDEY, R.; KHULLER, G.K. Polymer based drug delivery systems for mycobacterial infections. Curr. Drug. Deliv., v.1, p.195-201, 2004.
PING, He.; STANLEY, S.D.; LISBETH, I. In vitro evaluation of the mucoadhesive properties of chitosan microspheres. Int. J. Pharm., v.166, p.75-68, 1998.

PRICE, D.M. Temperature calibration of differential scanning calorimeters. J. Therm. Anal., v.45, p.1285-1296, 1995.

QIAN, J.; CHEN, W.; ZHANG, W.; ZHANG, H. Adulteration identification of some fungal polysaccharides with SEM, XRD, IR and optical rotation: a primary approach. Carbohydr. Polym., v.78, p.620-625, 2009.

SAMUELSON, A.B.; PAULSEN, B.S.; WOLD, J.K.; KNUTSEN, S.H.; YAMADA, H. Characterization of a biologically active arabinogalactan from the leaves of Plantago major L. Carbohydr. Polym., v.35, p.145-153, 1998.

SHASHIKANT, C.D.; SUDHIR, G.W.; AVINASH, K.D. Behavior of suspending and wetting agents in aqueous environment. Asian J. Pharm., v.1, p.9-12, 2009.

SHIRWAIKAR, A.; SHIRWAIKAR, A.; PRABU, S.L.; KUMAR, G.A. Herbal excipients in novel drug delivery system. Indian J. Pharm. Sci., v.70, p.415-422, 2008.

SHLOMO, T.; ALFRED, M.M. Composition and properties of Opuntia Ficus-Indica Mucilage. Phytochemistry, v.20, p.2665-2668, 1981.

SINGH, S.; SINGH, S.; SHETH, N.R.; ROSHAN, P.; USHIR, Y.V.; GENDLE, R. Colon specific drug delivery system of mesalamine for eradication of ulcerative colitis. Res. $J$. Pharm. Tec., v.2, p.443-447, 2009.

SINGH, S.; BOTHARA S.S. Acute toxicity studies of natural materials extracted from indigenously edible fruits available in chhattisgarh. Planta Acta, v.4, p.1-3, 2012.

SOUMEN, P.; BANDYOPADHYAY, A.K.; MUKHERJEE, S.; SAMADDAR, B.N.; PAL, P.G. Effect of agglomeration during co-precipitation: delayed spinellization of magnesium aluminate hydrate. Bull. Mater. Sci., v.33, p.451-456, 2010.

STOPIC, S.R.; ILIC, I.B.; USKOKOVIC, D.P. Effect of $\mathrm{P}_{\mathrm{d}}$, $\mathrm{Cu}, \mathrm{Ni}$ Additions on the Kinetics of $\mathrm{NiCl}_{2}$ Reduction by Hydrogen. Metall. Mater. Trans. A, v.28B, p.1241-1248, 1997. 
THIMMA, R.T.; SHEKHARAM, T. Free radical degradation of Guar gum. Polym. Degrad. Stabil., v.86, p.455-459, 2004.

VARMA, A.J.; KOKANE, S.P.; PATHAK, G.; PRADHAN, S.D. Thermal behavior of galactomannan guar gum and it's periodating oxidation products. Carbohydr. Polym., v.32, p.111-114, 1997.

VENDRUSCOLO, C.W.; FERRERO, C.; PINEDA, E.A.G.; SILVEIRA, J.L.M.; FREITAS, R.A.; JIMENEZCASTELLANOS, R.; BRESOLIN, T.M.B. Physicochemical and mechanical characterization of galactomannan from Mimosa scabrella: effect of drying method. Carbohydr. Polym., v.76, p.86-93, 2009.

VINOD, V.T.P.; SASHIDHAR, R.B.; SURESH, K.I.; RAMA RAO, B.; VIJAYA SARADHI, U.V.R.; PRABHAKAR RAO, T. Morphological, physico-chemical and structural characterization of gum kondagogu (Cochlospermum gossypium): a tree gum from India. Food Hydrocolloids, v.22, p.899-915, 2008.

VOGT, D.C.; STEPHEN, A.M.; JACKSON, G.E. ${ }^{1} \mathrm{H}$ NMR and $\mathrm{C}^{13}$ NMR spectroscopy of methyl ethers of D-galactopyranose. Carbohydr. Res., v.206, p.333-339, 1990.

WANG, Q.I.; ELLIS, P.R.; ROSS-MURPHY, S.B. Dissolution kinetics of guar gum powders - 1. Methods for commercial poly-disperse samples. Carbohydr. Polym., v.49, p.131137, 2002.
WANG, Q.I.; ELLIS, P.R; ROSS-MURPHY, S.B. Dissolution kinetics of guar gum powders - 3. Effect of particle size. Carbohydr. Polym., v.64, p.239-246, 2006.

WANG, Q.I.; ELLIS, P.R.; ROSS-MURPHY, S.B. Dissolution kinetics of guar gum powders 2: Effects of concentration and molecular weight. Carbohydr. Polym., v.53, p.75-83, 2003.

XIAODONG, M.; MAREK, P. Intrinsic viscosities and huggins constants of Guar gum in alkali metal chloride solutions. Carbohydr. Polym., v.70, p.15-24, 2007.

ZATZ, J.L.; KUSHLA, G.P. In: REIGER, M.M.; BANKER, G.S. (Eds.). Pharmaceutical dosage forms: disperse systems. 2.ed. New York: Marcel Dekker Inc., 1989. v.2, p.508.

ZOHURIAAN, M.J.; SHOKROLAHI, V.F. Thermal studies on natural and modified gums. Polym. Test., v.23, p.575-579, 2004.

Received for publication on $16^{\text {th }}$ January 2013 Accepted for publication on $19^{\text {th }}$ November 2013 
